\title{
Przemówienie na pogrzebie Profesora Wojciecha Ryszarda Rzepki (2 grudnia 2008)
}

Cóż powiedzieć nad grobem przyjaciela, który odszedł od nas nagle i przedwcześnie? Jakimi słowami wyrazić to, co przenika serce i umysł?

Z profesorem Wojciechem Ryszardem Rzepką (dla mnie Ryszardem, Ryśkiem lub - rzadziej - Wojtkiem) przyjaźniłem się od lat. Przez lata tworzyliśmy jeden z najwytrwalszych i najzgodniejszych tandemów autorskich (wspólnie opublikowaliśmy ponad 40 prac). Wprawdzie z czasem, z różnych względów, ta współpraca się urwała, jednak niedawno powróciliśmy do niej, publikując wspólnie rozprawę o staropolskich rozkaźnikach w księdze jubileuszowej profesora Wacława Twardzika. Ryszard (tej formy będę używał, bo zmarły - choć nie wiem, dlaczego - chyba wolał swoje drugie imię) wprowadził mnie też w krag władz akademickich Uniwersytetu im. Adama Mickiewicza, proponując następstwo po sobie na urzędzie dziekana Wydziału Filologii Polskiej i Klasycznej. Społeczność akademicka w wolnych wyborach zaaprobowała wolę swojego ustępującego Dziekana.

Oczywiście wszyscyśmy wiedzieli (wiedziała o tym cała językoznawcza Polska), że od paru lat Ryszarda trawiła ciężka choroba, która poważnie ograniczała jego aktywność naukową, dydaktyczną i organizacyjną. Wydawało się jednak, że jego stan jest w miarę stabilny i że możemy jeszcze oczekiwać (choć musiał wydatnie spowolnić tempo pracy) niejednej świetnej, nowatorskiej publikacji. Gdym się z nim widział „w te dni przedostatnie” (o których nikt nie mógł wiedzieć, że są przedostatnie), rozmawiał jeszcze ze mną o kolejnej finalizowanej pod jego kierunkiem rozprawie doktorskiej, proponując mi funkcję recenzenta. Miał więc jeszcze jakieś plany, zapewne także naukowe. Miał przecież dopiero 68 lat... 
A dziś, tu, nad grobem, niepodobna uniknąć refleksji: jakże kruche jest życie ludzkie! Zaiste, jest człowiek jak trzcina na wietrze albo ,jako proch, jenże rzuca wiatr od oblicza ziemie". Zasadnie pisał Horacy:

Tak, przyjacielu! Przez nurty tej strugi my wszyscy, którzy chleb jemy powszedni, śmiertelnej musim podjąć się żeglugi, czyśmy królowie, czy kmiotkowie biedni!

Tylko się ciśnie na usta pytanie: dlaczego już? Dlaczego tak wcześnie? Dlaczego to mnie przypadło żegnać Cię, Ryszardzie, nad grobem? Gdy brak słów, zawsze się można uciec do strof rzymskiego poety:

A jeśli ciebie, duszy mej połowę, pojmie wcześniejsze śmierć, to wtedy rzecie niechaj grom pada i na moją głowę, bo ból mi jeno, jeno żal na świecie.

Nie tylko mnie - nam wszystkim (są tu przedstawiciele środowisk językoznawczych całej Polski) jeno ból i żal na świecie. Odszedł uczony - twierdzę to z całą odpowiedzialnością za słowo - wielki, wybitny i niezastąpiony. Jego książki to niedościgły wzór naukowej sumienności, filologicznej akrybii i precyzyjnego wnioskowania. Jego studia i rozprawy to częstokroć prace otwierające nowe horyzonty badawcze i inicjujące nowe kierunki badań. Odszedł wyjątkowo skrupulatny i ofiarny nauczyciel akademicki, niezrównany opiekun naukowy i promotor znakomitych rozpraw magisterskich i doktorskich. Zasłużony organizator życia naukowego i akademickiego - dyrektor Instytutu Filologii Polskiej naszej Almae Matris, pierwszy dziekan Wydziału Filologii Polskiej i Klasycznej (po reorganizacji struktury uniwersyteckiej), kierownik Zakładu Języka Polskiego i Zakładu Historii Języka Polskiego, też Zakładu Historii Języka Polskiego na Uniwersytecie Szczecińskim, główny redaktor wydawnictw Poznańskiego Towarzystwa Przyjaciół Nauk, członek Komitetu Językoznawstwa Polskiej Akademii Nauk, przewodniczący zespołu ekspertów polonistycznych Uniwersyteckiej Komisji Akredytacyjnej, członek Centralnej Komisji do spraw Stopni i Tytułów, członek komitetów redakcyjnych kilku ogólnopolskich periodyków językoznawczych oraz Stownika języka polskiego XVII i 1. polowy XVIII wieku... Nawet się nie silę, by wymienić tu wszystkie ważne i wzorowo wypełniane funkcje akademickie Ryszarda.

Przede wszystkim jednak odszedł dobry i życzliwy całemu światu człowiek. Powściagliwy w okazywaniu uczuć, niezbyt wylewny, pilnie strzegący 
swojej prywatności (choć przyjaciel, niewiele w gruncie rzeczy wiedziałem o jego życiu prywatnym i rodzinnym), lecz równocześnie bardzo ciepły, serdeczny, taktowny i ofiarnie spieszący z pomocą, wskazówką czy dobrą radą. Iluż z nas zawdzięcza mu bardzo wiele, a niektórzy - w płaszczyźnie naukowej i zawodowej - właściwie niemal wszystko!

I człowiek - niepodobna o tym nie wspomnieć, bo był to uderzający wszystkich rys charakteru Ryszarda - wyjątkowej skromności. Dlatego wiem, że nigdy sam by o sobie nie powiedział tego, co jednak musi tutaj być powiedziane, horacjańskim wierszem:

Exegi monumentum aere perennius

regalique situ pyramidum altius, quod non imber edax, non aquilo impotens possit diruere...

Wzniósł sobie Ryszard taki pomnik, trwalszy od spiżu i wyższy od piramid, odporny na deszcz i wichry - w naszych sercach. Nigdy by też nie powiedział:

Non omnis moriar multaque pars mei vitabit Libitinam...

Ale istotnie nie wszystek umrze, bo wiecznie będzie żył w pamięci korzystających z wyników jego prac pokoleń językoznawców i w pamięci dziesiątków tysięcy studentów polonistyki, którzy z jego znakomitej Chrestomatii staropolskiej (przygotowanej we współpracy z profesorem Wiesławem Wydrą) poznają i będą poznawać teksty ilustrujące historyczną ewolucję naszego języka ojczystego.

I wreszcie - jakkolwiek tym razem może i z innych powodów - chyba by Ryszard o sobie nie powiedział - a to też powinno być tutaj powiedziane - za św. Pawłem: „W dobrych zawodach wystapiłem, bieg ukończyłem [...]. Na ostatek odłożono dla mnie wieniec sprawiedliwości, który mi w owym dniu odda Pan, sprawiedliwy Sędzia [...]”.

Drogi Ryszardzie, nieodżałowany przyjacielu - odpoczywaj w pokoju, boś się był bardzo utrudził. Sit tibi terra levis! 
